\title{
Development of Scientific and Methodical Competence of Teachers of Vocational Education Institutions
}

\section{Desarrollo de la competencia científica y metódica de docentes de instituciones de educación vocacional}

\section{Volodymyr S. Kulishov*}

Bila Tserkva Institute of Continuous Education, University of Educational Management of the National Academy of Educational Sciences of Ukraine, Bila Tserkva, Ukraine ORCID: https://orcid.org/0000-0003-3262-796X

Yurii A. Skyba

Institute of Higher Education of the National Academy of Educational Sciences of Ukraine, Kyiv, Ukraine

ORCID: https://orcid.org/0000-0003-2238-8272

\section{Andrii B. Yermolenko}

Bila Tserkva Institute of Continuous Education, University of Educational Management of the National Academy of Educational Sciences of Ukraine, Bila Tserkva, Ukraine ORCID: https://orcid.org/0000-0003-3048-7844

\section{Svitlana S. Shevchuk}

Bila Tserkva Institute of Continuous Education, University of Educational Management of the National Academy of Educational Sciences of Ukraine, Bila Tserkva, Ukraine

ORCID: https://orcid.org/0000-0001-6260-3323

\section{Tetyana P. Shchypska}

Bila Tserkva Institute of Continuous Education, University of Educational Management of the National Academy of Educational Sciences of Ukraine, Bila Tserkva, Ukraine

ORCID: https://orcid.org/0000-0003-1649-3789

Received 09-08-20 Revised 10-10-20

*Correspondence

Email: v.kulishov6285@murdoch.in
Accepted 20-12-21 On line 02-12-21

Cite as:
Kulishov, V.S., Skyba, Y.A., Yermolenko, A.B., Shevchuk, S.S.\&
Shchypska, T.P. (2021). Development of Scientific and Methodical
Competence of Teachers of Vocational Education Institutions.
Propósitos y Representaciones, 9(SPE2), e994. Doi:
http://dx.doi.org/10.20511/pyr2021.v9nSPE2.994

(c) Universidad San Ignacio de Loyola, Vicerrectorado de Investigación, 2021. 


\section{Summary}

The relevance of the studied problem is due to the growing requirements for scientific and methodical training of teachers of vocational education institutions in Ukraine in the context of improving the efficiency of the educational process of future skilled workers. The aim of the article was to investigate theoretically and to test experimentally the effectiveness of modern approaches to the development of scientific and methodical competence of teachers of vocational education institutions in Ukraine. Leading methods of research of this problem are empirical (questionnaires of teachers of vocational education institutions, observation and evaluation of the effectiveness of their scientific and methodical activities) and theoretical (comparative and substantive analysis of literature sources and regulations on the research topic, a systematic approach to the structure and modeling of the development of scientific and methodical competence of the teacher of vocational education institution on modern principles). It was developed and represented the structure and define levels of development of scientific and methodical competence of the teacher of vocational education institution, and also describe the process of development of scientific and methodical competence by improving the content and procedural components of advanced training of teachers of vocational education institutions. The materials of the article will be useful to the managers of vocational education institutions in the context of improving the scientific and methodical work of the institution, lecturers of postgraduate education institutions, whose activities are directly related to the professional development of pedagogical staff of vocational education institutions.

Keywords: scientific and methodical competence, professional activity, content and procedural components, advanced training.

\section{Resumen}

La relevancia del problema estudiado se debe a los crecientes requisitos de formación científica y metódica de los profesores de las instituciones de educación profesional en Ucrania en el contexto de la mejora de la eficiencia del proceso educativo de los futuros trabajadores cualificados. El objetivo del artículo era investigar teóricamente y probar experimentalmente la eficacia de los enfoques modernos para el desarrollo de la competencia científica y metódica de los profesores de las instituciones de educación profesional en Ucrania. Los principales métodos de investigación de este problema son empíricos (cuestionarios a profesores de instituciones de educación profesional, observación y evaluación de la efectividad de sus actividades científicas y metódicas) y teóricos (análisis comparativo y sustantivo de fuentes bibliográficas y normativas sobre el tema de investigación). Se desarrolló y representó la estructura y definió los niveles de desarrollo de la competencia científica y metódica del docente de la institución de educación vocacional, y también describió el proceso de desarrollo de la competencia científica y metódica mediante la mejora del contenido y los componentes procedimentales de la formación avanzada de los docentes de instituciones de educación vocacional. Los materiales del artículo serán útiles para los gerentes de instituciones de educación vocacional en el contexto de mejorar el trabajo científico y metódico de la institución, profesores de instituciones de educación de posgrado, cuyas actividades están directamente relacionadas con el desarrollo profesional del personal pedagógico de la educación vocacional instituciones.

Palabras clave: competencia científica y metódica, actividad profesional, componentes de contenido y procedimiento, formación avanzada. 


\section{Introduction}

An effective system of professional training of working staff, which can quickly adapt to the demands of the labor market and provide the manufacturing sector with skilled workers, is necessary for the socio-economic development of any country. Significant changes in the organization of professional training in Ukraine recently are associated with the growing demands of the labor market to qualified working staff, which must be able to perform their functions in the conditions of introduction of science-intensive technologies, computerization and technical re-equipment of industries and services (Order of the Cabinet..., 2019). The key role in the training of competitive specialists belongs to the teachers of vocational education institutions - teachers of professional and theoretical training and masters of industrial training. Therefore, the problem of quality training of working staff in Ukraine can be solved in at least two ways: by introducing anticipatory changes in the system of training skilled workers; by implementing modern approaches to the development of professional competence of teachers of vocational education institutions in the system of continuing education (Vinichenko et al., 2018a).

The problem of modeling the professional activity of teacher of vocational education institution is reflected in the research of G. Ball (2000), O. Kovalenko et al. (2007), N. Nychkalo (2004), V. Oliynyk (2003), L. Sergeeva (2011), V. Radkevych (2011), P.K. Misra (2011), M. Sirk et al. (2016). However, the essence of understanding the professional competence of a teacher is interpreted differently by different scholars. V.N. Vvedensky (2003) understands the professional competence of a teacher as his ability to carry out effectively professional activity that is, mastering modern ways of organizing the educational process and successful completion of professional tasks. This interpretation is not limited to the sum of knowledge and skills of the teacher, but determines the readiness to apply effectively them in educational and professional practice. According to S. Abdieva (2020), the professional competence of a teacher is a set of integration competencies needed to solve various educational tasks at different levels.

In our research, we consider the professional competence of the teacher of vocational education institution, taking into account the specifics of his activity, which, according to P. Andersson and S. Köpsén (2015), is based on two main competencies: learning competence and competence related to specific production experience. Accordingly, we interpret the professional competence of the teacher of vocational education institution as integrated professional quality, which allows the teacher to turn the process of learning the profession into a comprehensive way of forming the student's personality, and also reflects the abilities of the teacher to independently and effectively solve educational and production problems on the basis of knowledge, skills, experience of communicative and other personal qualities. The Law of Ukraine No. 103/98-VP "On Vocational Education" (1998) states that pedagogical staff of vocational education institutions conducts educational, methodical, disciplinary and organizational work related to the provision of educational services.

Our research is devoted to improving the professional competence of teachers of vocational education institutions, in the context of development and implementation in practice of their scientific and methodical potential, to increase the efficiency of training future skilled workers. The aim of the article is to investigate theoretically and to test experimentally the effectiveness of modern approaches to the development of scientific and methodical competence of teachers of vocational education institutions in Ukraine. 


\section{Materials and methods}

The methodical work is an important component of the professional activity of a teacher of vocational education institution. Properly organized methodical work in vocational education institution promotes the development of methodical competence of teachers. According to E.S. Aleshina (2019), it is possible to allocate two important directions in the structure of methodical work of the teacher: educational and methodical direction, focused on raising the general level of professional and pedagogical culture, pedagogical skills, as well as methodical support of the educational process; research direction that stimulates the formation of innovative component of the teaching staff activity, the process of creating and implementing new educational technologies, the latest methodical support, development and implementation of experimental projects.

Other researchers S.V. Tolochko and N.M. Ridey (2017) hold the opinion that the educational and methodical work of the teacher is to master the existing knowledge in science and to study the experience of teaching experienced colleagues and recognized in the world of pedagogical science professionals. The essence of scientific and methodical work of teachers' scientists consider in independent scientific research and in formation of personal style and own personnel technology.

In our research, taking into account the specifics of the activities of the teacher of vocational education institution, we consider the effectiveness of the implementation of the teacher of educational and methodical and scientific and methodical work in vocational education institutions through the development of his scientific and methodical competence, consisting of methodical (scientific and methodical) and special (scientific and professional) aspects. So, scientific and methodical competence, in our opinion, is a component of the professional competence of the teacher and largely characterizes his ability to effectively design, organize, adjust, evaluate and systematically work on improving the process of professional-theoretical and professional-practical training of specialists (Khalimon et al., 2019a; Vasylieva et al., 2020).

Experimental work was carried out on the basis of vocational education institutions of Dnipropetrovsk, Poltava and Sumy regions of Ukraine:

- $\quad$ SEI "Dnipro Center for Vocational Education" (Dnipro);

- $\quad$ SEI "Vocational School 26" (Kremenchuk, Poltava region);

- $\quad$ SVEI "Sumy Higher Vocational School of Construction and Design" (Sumy);

- $\quad$ "Regional Center for Vocational Education" (Zinkiv, Poltava region);

- SEI "Kryvyi Rih Center for Vocational Education in Metallurgy and Mechanical Engineering" (Kryvyi Rih, Dnipropetrovsk region).

In total, 98 teachers were involved in the experiment -45 masters of industrial training and 53 teachers of professional and theoretical training. Leading methods of research of this problem are:

empirical (observation, questionnaire, method of expert evaluations, performance evaluation, testing);

- theoretical (comparative and substantive analysis of literature sources and regulations on the research topic, a systematic approach and modeling methods); theory); mathematical (methods of statistical data processing, methods of probability graphic (graphic figures, tables). 
The research was conducted in three main stages:

at the first stage we carried out the analysis of philosophical, psychological and pedagogical scientific sources on the research topic in order to identify theoretical and practical existing approaches to the development of scientific and methodical competence of teacher of vocational education institution, substantiated the relevance of research, defined the purpose and main methods of research;

at the second stage we clarified the structure and the content of scientific and methodical competence of the teacher of vocational education institution, carried out experimental researches for the purpose of taking into account inquiries of teachers of vocational education institutions as for improvement of their scientific and methodical potential, carried out adjustment of the content and procedural components of advanced training of teachers of vocational education institutions in the course and intercourse periods;

at the third stage we completed experimental researches, generalized and systematized the obtained results, implemented developed modern approaches to the development of scientific and methodical competence of teachers in the educational process of advanced training at the Bila Tserkva Institute of Continuing Professional Education.

A questionnaire containing 18 questions was developed for the ascertaining stage of the research. The purpose of the survey was to determine the levels of development of scientific and methodical competence of teachers of professional and theoretical training and masters of industrial training and their respective requests for improving the process of advanced training in the course and intercourse periods. As part of the formative stage of the research, we made adjustments of the content component of advanced training of teachers of vocational education institutions. Accordingly, we developed working curricula and training and methodical support for elective special courses, which were aimed at the development of scientific and methodical competence of teachers and readiness to implement innovative approaches in the professional training of students (Vinichenko et al., 2018b).

An educational electronic resource was created on the website of the Department of Methods of Professional Education and Social and Humanitarian Disciplines (2020), which contained materials of ongoing International and Ukrainian scientific and practical Internet seminars on the professional orientation of teachers and scientific and methodical problems of vocational training of skilled workers. The presented materials highlight the problems of increasing the innovative capabilities of the educational process, and create favorable conditions for teachers to prioritize the development of accessibility, quality and effectiveness of training specialists in the vocational education system. To improve the procedural component of advanced training in the course and intercourse periods scientific and pedagogical staff of the Department of Methods of Professional Education and Social and Humanitarian Disciplines decided at the stage of the test session and in the intercourse period to regularly hold scientific and practical seminars and conferences of various levels (regional, all-Ukrainian, international). It allows attracting experienced teachers of the leading vocational education institutions of Ukraine and abroad to exchange experience in the application of educational innovations in the training of competitive workers and providing opportunities for vocational school teachers to publish personal developments in electronic or printed publications.

\section{Results}

\section{The structure of scientific and methodical competence of a teacher}

Based on the analysis of the functional responsibilities of pedagogical staff of vocational education institutions, we have found that the structure of the methodical (scientific and methodical) aspect of scientific and methodical competence is multilevel and multifaceted and 
has, in our opinion, the following components: conceptual (knowledge of the theoretical foundations of professional activity), instrumental (possession of basic professional skills), technological (possession of modern learning technologies), information (possession of modern means of informatization of the educational process), adaptive (the ability to anticipate changes in the educational environment and be prepared for them). The special (scientific and professional) component of scientific and methodical competence is characterized by the level of production knowledge and skills in the context of the taught discipline. Scientific research (Andersson \& Köpsén, 2015; Oliynyk, 2003; Silaeva, 2018; Zaslavska, 2015; Zashchirinskaia, 2020a; Zashchirinskaia, 2020b) allow to differentiate the content of special competence of teachers that is, to determine its components for masters of industrial training and teachers of professional and theoretical training of vocational education institutions.

We propose to introduce variable components into the structure of special competence, which determine the specifics of their educational activities. Professional and technological component for teachers of professional and theoretical training contains knowledge, skills and pedagogical experience in the implementation of theoretical knowledge about the latest production technologies into the professional training of skilled workers. Professional and practical component for masters of industrial training includes the formation of practical skills to master modern tools and technologies for specific types of production tasks.

During the research it is found out that the professional and practical and professional and technological components of special competence are realized at the level of the following professional functions of the teacher of vocational education institution: scientific and adaptive function (the ability to identify contradictions in the development of phenomena and processes, formulate problems, generate ideas and hypotheses for solving problematic training and production situations, receive and present the results of scientific and methodical activities); engineering and technical function (ability to design and construct products, adjustment and repair of equipment, mastery of methods of innovation and inventive activity); information and design function (possession of information technologies, the ability to develop educational software (software product) in the organization the training of the profession, knowledge of software design methods) (Vinichenko et al., 2018c; Skydan et al., 2019; Golub et al. 2020).

The general structure of scientific and methodical competence of the teacher of vocational education institution is presented in Figure 1. Definition the structure of methodical and special competencies (as components of scientific and methodical competence) allows to implement a systematic approach to the selection of all components of the educational process while improving the system of advanced training of pedagogical staff of vocational education institutions. 


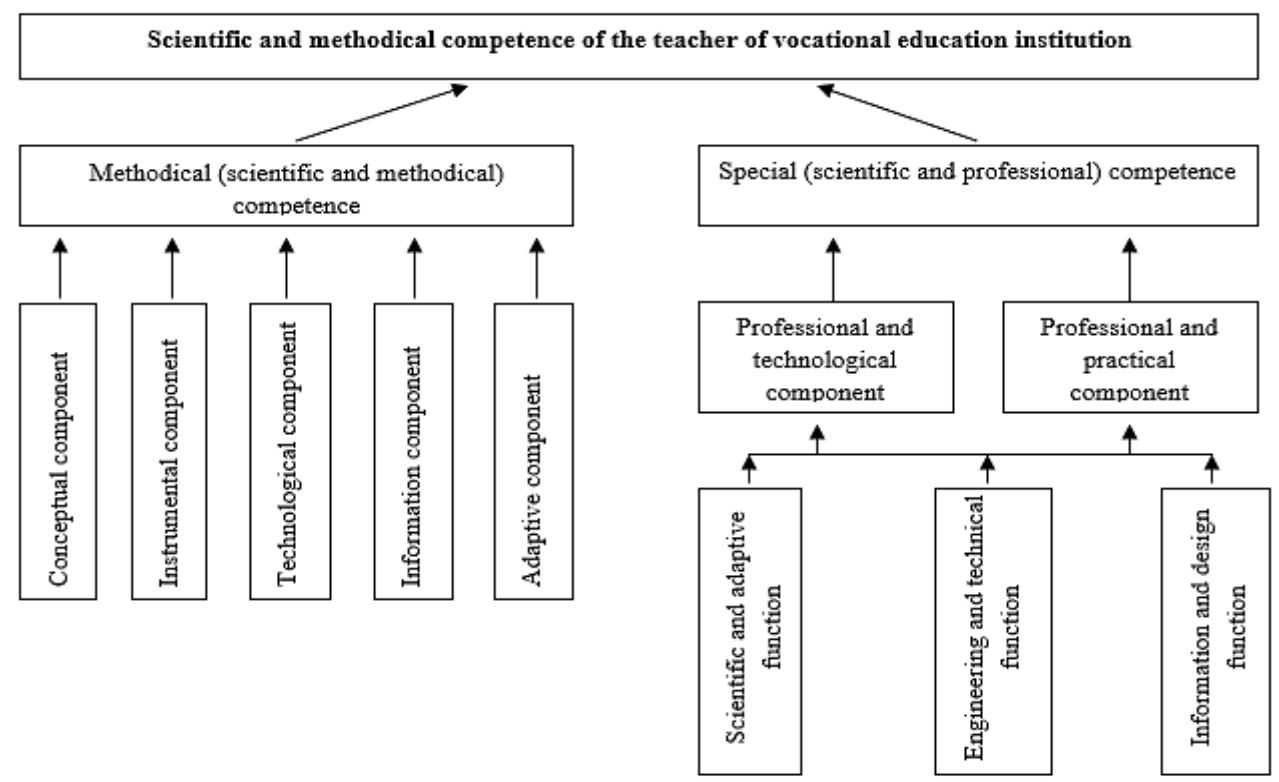

Figure 1. The structure of scientific and methodical competence of the teacher of vocational education institution

During the research we offer development of scientific and methodical competence of teachers of vocational education institutions to define based on stereotypical, diagnostic and heuristic levels of their activities. Stereotypical activity of the pedagogical worker assumes possession of the general knowledge of methods of professional training, understanding of certain issues of scientific and methodical activities, which allows for professional training of students at the adaptive level. It is characterized by the ability to perform certain elements of scientific and methodical activities in typical pedagogical situations, according to precise instructions, under the direct control of the methodist (or senior master). Diagnostic level of activity involves the possession of systematized special knowledge, understanding of the principles, theories and methods of professional training of specialists. It is characterized by the ability to perform scientific and methodical activities in atypical pedagogical situations, by selecting appropriate methods and techniques, partially exercising self-control of pedagogical activity. Heuristic level of activity is characterized by the possession of deep special knowledge in the field of didactics and methods of professional training; there is a critical understanding of the principles, theories and methods of professional training of specialists. The pedagogical worker is able to perform scientific and methodical work in situations of uncertainty, to find innovative approaches to their solution, fully exercising self-control of pedagogical activity.

\section{The results of experimental researches}

The data obtained during the ascertaining experiment indicate the following:

The availability of pedagogical education for teachers and masters is respectively $48 \%$ and $33 \%$, which determines the importance of non-formal and informal psychological, pedagogical and methodological training for effective professional activity.

Deep special knowledge, according to respondents, have $12 \%$ of teachers, systematized special knowledge $65-74 \%$, basic general knowledge $13-23 \%$. The obtained data allow us to conclude that the teachers of advanced training courses are well versed in the methods of teaching the profession, which provides prospects for improving the content component of the educational process.

Diagnostic level of activity on the organization of effective educational work of students, design of educational process, planning and organization of innovative lessons and preparation of modern educational and methodical support of classes are typical for the majority 
of respondents: from $49 \%$ to $63 \%$. These results are the basis for improving the procedural component of the educational process of advanced training through the introduction of modern learning technologies.

The majority of respondents testified to the readiness to implement modern educational innovations in their own educational and methodical activities (44-51\%), which creates the preconditions for the development of an educational environment for the exchange and application of modern pedagogical practices.

About $50 \%$ of respondents have publications on the results of pedagogical activities in periodicals and collections of conferences and seminars. However, as research has shown, this trend is growing and in the future every teacher (from respondents) wants to have a publication (or several), which will be taken into account when developing modern approaches to advanced training.

- Participants of experimental groups submitted proposals to supplement the topics of content modules, which revealed the issues of innovative methodical work in vocational education institutions and modern training and production approaches to the organization of the educational process.

Organization and carrying out of actual scientific and methodical and scientific and practical actions (including professional orientation) in course and intercourse periods of advanced training, which will promote the development of scientific and methodical competence of teachers.

The need to introduce short-term elective courses on modern problems of professional training of skilled workers with certificates, creating an open educational environment for the exchange of promising experience between teachers of vocational education institutions of Ukraine and abroad.

The general results of the ascertaining stage of the research are presented in Table 1.

Table 1. Levels of development of scientific and methodical competence of the teachers of vocational education institutions according to the results of the ascertaining experiment

\begin{tabular}{|c|c|c|c|c|c|}
\hline \multirow{2}{*}{ No. } & \multirow{2}{*}{$\begin{array}{c}\text { Levels of } \\
\text { development }\end{array}$} & \multicolumn{2}{|c|}{$\begin{array}{c}\text { Teachers of professional and theoretical } \\
\text { training }\end{array}$} & \multicolumn{2}{|c|}{$\begin{array}{c}\text { Masters of industrial } \\
\text { training }\end{array}$} \\
\cline { 3 - 6 } & & People & $\%$ & People & $\%$ \\
\hline 1. & Stereotypical & 13 & 24.5 & 17 & 37.8 \\
\hline 2. & Diagnostic & 30 & 56.6 & 20 & 44.4 \\
\hline 3. & Heuristic & 10 & 18.9 & 8 & 17.8 \\
\hline
\end{tabular}

As we can see, according to the results of the survey prevail diagnostic (for teachers) and diagnostic and stereotypical (for masters) levels of development of scientific and methodical competence, which opens prospects for improving the process of development of scientific and methodical competence of teachers of vocational education institutions on a modern basis. Thus, the ascertaining stage of the research allowed to determine the directions of improvement of the content and procedural components in the structure of advanced training courses and to plan the preparation of a system of activities in the course and intercourse periods according to the requests of teachers (Khalimon et al., 2019b; Skydan, 2011).

In addition, changes in working curricula were justified in order to differentiate the complexity and increase the percentage of practice-oriented classes conducted for:

formation and development of teachers' skills for the introduction of innovative learning technologies and the latest production technologies in the training of students of vocational education institutions (educational trainings, master classes, methodical briefings); 
- discussion, evaluation of the effectiveness and dissemination of modern educational practices (seminars, webinars, scientific and practical conferences);

- $\quad$ improving the skills of teachers to develop modern educational and methodical support for the professional training of skilled workers, documents on planning of professional and practical and professional and theoretical training in vocational education institutions (practical classes);

gaining the experience in solving situational professional tasks (managed independent work on tasks of different levels of complexity, thematic discussions).

The content and procedural components of advanced training, adjusted at the request of the teachers, were introduced into the educational process of the experimental groups of teachers of vocational education institutions. Questionnaires of teachers during the control stage of the research were conducted according to the same methods as at the ascertainment stage. The data of the control questionnaire allowed us to draw the following conclusions:

- $\quad$ more than $90 \%$ of teachers of professional and theoretical training and about $75 \%$ of masters of industrial training stated the importance of psychological, pedagogical and methodical training for the effective organization of the educational process in vocational education institutions;

about $21 \%$ of respondents have deep special knowledge on the methods of teaching the profession, $68-75 \%$ of respondents have systematized special knowledge, $8-13 \%$ of teachers have basic general knowledge;

diagnostic and heuristic levels of activity of teachers concerning the organization of educational work of students, designing of educational process, planning and the organization of innovative lessons and preparation of modern educational and methodical support of classes are revealed as prevailing;

- $\quad$ about $74 \%$ of surveyed teachers regularly publish the results of pedagogical activities in periodicals and collections of conferences and seminars;

- the vast majority of respondents (about 87\%) stated the relevance and importance of scientific and methodical and scientific and practical activities (including professional orientation) in the course and intercourse periods of advanced training;

almost $100 \%$ of respondents noted the effectiveness of the use of electronic educational resources of the Department of Methods of Professional Education and Social and Humanitarian Disciplines.

The general results of the control stage of the research are presented in Table 2 .

Table 2. Levels of development of scientific and methodical competence of the teachers of vocational education institutions according to the results of the control experiment

\begin{tabular}{|c|c|c|c|c|c|}
\hline \multirow{2}{*}{ No. } & \multirow{2}{*}{$\begin{array}{c}\text { Levels of } \\
\text { development }\end{array}$} & \multicolumn{2}{|c|}{$\begin{array}{c}\text { Teachers of professional and theoretical } \\
\text { training }\end{array}$} & \multicolumn{2}{c|}{$\begin{array}{c}\text { Masters of industrial } \\
\text { training }\end{array}$} \\
\cline { 3 - 6 } & & People & $\%$ & People & $\%$ \\
\hline 1. & Stereotypical & 5 & 9.4 & 11 & 24.4 \\
\hline 2. & Diagnostic & 31 & 58.5 & 22 & 48.9 \\
\hline 3. & Heuristic & 17 & 32.1 & 12 & 26.7 \\
\hline
\end{tabular}

The control stage of the research allowed monitoring the dynamics of development of scientific and methodical competence of teachers of vocational education institutions. According to it the teachers of professional and theoretical training of experimental groups were dominated by diagnostic and heuristic levels of development of scientific and methodical competence (increased by $1.9 \%$ and $13.2 \%$, respectively, compared to the results of ascertaining stage of research). The masters of industrial training of experimental groups also were recorded 
at a positive dynamic of development of scientific and methodical competence, evidence of which was the increase in the number of persons with diagnostic (by 4.5\%) and heuristic (by $8.9 \%$ ) levels of development scientific and methodical competence. The presented statistics confirm the effectiveness and timeliness of the proposed changes in the structure of advanced training of teachers of vocational education institutions at the level of content and procedural components.

\section{Discussions}

The study and analysis of special domestic and foreign scientific sources allow us to conclude that the problem of development of scientific and methodical competence of teachers of vocational education institutions has not been particularly studied in pedagogical theory and practice. However, some aspects of scientific and methodical activities of teachers have been the subject of research by a number of scientists:

- formation of scientific and methodical competence of a teacher of a higher education institution in connection with innovative approaches to the organization of his professional activity (Stepanets, 2020);

development of methodical competence of a music teacher in the context of special scientific and pedagogical training and creation of necessary conditions for activation of his scientific and methodical potential (Aleshina, 2019);

formation of scientific and methodical competence of teachers in the system of postgraduate pedagogical education for effective support of the educational process (Tolochko \& Ridey, 2017);

management of scientific and methodical work of the teacher of vocational education institution on the basis of the project-target approach (Shakuto et al., 2016);

- peculiarities of methodical training of teachers of vocational education institutions and gymnasium teachers (Csíkos et al., 2018).

The formation of the need of a modern teacher of vocational education institution in the improvement of scientific and methodical competence is connected, first of all, with an awareness of the goals and objectives set before him by his professional affiliation, as well as with a real assessment of his professional capabilities and readiness to implement them through activities, including innovation (Kostruba, 2018a). The process of development of scientific and methodical competence in the context of general improvement of continuing professional education of teachers of vocational education institutions is impossible without taking into account along with the general methodical principles of its functioning also andragogical principles, which emphasize the specifics of the adult audience. The research has taken into account the following specific characteristics of the adult learning process:

- $\quad$ each teacher realizes himself as an independent person;

- $\quad$ adults have a stock of life, professional and social experience, which can be one of the sources of learning;

- $\quad$ the main motive for learning adults determines the desire to solve their vital (including professional) problems and achieve specific goals;

- $\quad$ adults strive for immediate realization of the acquired knowledge and skills;

- the activity nature of learning is usually dominated in adult education: theoretical knowledge must be confirmed in practice.

The system of approaches, which improves the scientific and methodical component of the professional activity of a teacher today, does not take into account the differentiation of goals, content, methodical and organizational aspects of advanced training courses depending on the initial level of professional training, which is determined by the results of incoming 
diagnostic testing (Kostruba, 2018b). This is primarily due to the fact that the principle of formation of individualized content and procedural components of the system of advanced training based on existing teaching experience is not always appropriate and objective. This statement is based on the fact that quite often graduates of engineering and pedagogical institutions of higher education of III-IV levels of accreditation have knowledge and skills in methods of teaching the profession at a higher level than, for example, a master of industrial training with more than 10 years of teaching experience, who has no basic pedagogical education, and has received pedagogical knowledge and skills through advanced training and informal education. Thus, the above principles of development of scientific and methodical competence of the teacher of vocational education institution in Ukraine in the research are justified in accordance with the modern specifics of his professional and pedagogical activities, which take into account:

- $\quad$ requirements of customers of working staff;

- $\quad$ the specifics of the development of enterprises in the region;

- $\quad$ opportunities for the implementation of their own educational projects;

- $\quad$ combination of industrial training with productive practice;

- $\quad$ focus on the group of working professions and professional and qualification requirements for future workers.

As the positive assessment of scientific and methodical activity of the teacher of vocational education institution testifies to qualitative characteristics of his professional potential, the scientific and methodical achievements of the teacher on the basis of conscientious performance of his professional duties, observance of scientific and methodical recommendations, use of already known, but effective and modern forms and methods, means and methods of work, which leads to positive results, are also indicators of the competence of the teacher and contribute to his development as a professional. As a result, scientific and methodical competence is one of the keys in the professional activity of a teacher of vocational education institution. It is characterized not so much by the amount of knowledge and professional experience, as the ability to update them at the right time and use in the process of activity. The basis for its formation and development are the peculiarities of the organization of the educational process in vocational education institution.

\section{Conclusions}

During the research it is found out that the scientific and methodical activity of the teacher of vocational education institution is a priority for the effective implementation of the educational process. It focuses, on the one hand, on improving one's own teaching skills by expanding, deepening and updating professional knowledge, acquaintance with modern innovative educational technologies and interactive forms and methods of their introduction into educational process. On the other hand, such activity presupposes the teacher's possession of special knowledge and skills in the relevant professional (scientific) field and his ability to combine theory and practice in solving professional tasks and problems. Thus, the research, as well as the analysis of practical pedagogical experience in vocational education institutions has shown the need and importance of creating conditions for the development of scientific and methodical competence of teachers on a modern basis. Designing the content and procedural components of the system of development of scientific and methodical competence of teachers of vocational education institutions on modern principles allowed creating optimal educational environment for the implementation of personality-oriented approach to meeting the professional needs of teachers, creating opportunities for the development of their creative potential, motivation for innovation activity, differentiation and individualization of the learning process in vocational education institutions. 
The materials of the article will be useful to the managers of vocational education institutions (directors, deputy directors, methodists, senior masters) in the context of improving the scientific and methodical work of the institution, lecturers of postgraduate education institutions, whose activities are directly related to the professional development of pedagogical staff of vocational education institutions, everybody who is interested in the development of scientific and methodical competence of teachers and the improvement of scientific and methodical aspects of the activities of teachers in modern educational institutions.

\section{References}

Abdieva, S. (2020). Structure and principles of modeling professional competence of the future teacher-bachelor in the process of professional training. Journal of Critical Reviews, 7(2), 397-401. DOI: 10.31838/jcr.07.02.77.

Aleshina, E.S. (2019). Scientific and Methodical Activities of a Modern Music Teacher. In book: Development of the Modern Education System: Theory, Methodology, Experience, pp. 111-114. Cheboksary: Publishing House "Sreda".

Andersson, P., Köpsén, S. (2015). Continuing professional development of vocational teachers: Participation in a Swedish national initiative. Empirical Research in Vocational Education and Training, 7, article number 7. DOI: 10.1186/s40461-015-0019-3.

Ball, G. (2000). Humanization of Secondary and Vocational Education: Social Relevance and Psychological and Pedagogical Guidelines. In book: I.A. Zyazyun (Ed.). Continuing Professional Education: Problems, Searches, Prospects, pp. 134-158. Kyiv: Vipol.

Csíkos, C., Kovács, Z., Kereszty, O. (2018). Hungarian vocational education teachers' views on their pedagogical knowledge and the information sources suitable for their professional development. Empirical Research in Vocational Education and Training, 10, article number 2. DOI: 10.1186/s40461-018-0063-X.

Golub, G., Skydan, O., Kukharets, V., Yarosh, Y., Kukharets, S. (2020). The estimation of energetically self-sufficient agroecosystem model. Journal of Central European Agriculture, 21(1), 168-175.

Khalimon, E., Brikoshina, I., Guseva, M., Kogotkova, I., Nikitin, S. (2019a). National projects as a way to solve the problems of economic and digital disparities in different areas and regions. In: 5th IPMA SENET Project Management Conference (SENET) - Challenges of Growing Economies, pp. 105-111. Belgrade: Serbian Project Management Assoc.

Khalimon, E.A., Guseva, M.N., Kogotkova, I.Z., Brikoshina, I.S. (2019b). Digitalization of the Russian economy: first results. In: International Scientific Conference on Global Challenges and Prospects of the Modern Economic Development (GCPMED), pp. 199213. Samara: Samara State Univ Econ.

Kostruba, A.V. (2018a). Law enforcement as a form of realization of right: phenomenological analysis experience (civilized aspect). Revista de Derecho Civil, 5(1), 177-190.

Kostruba, A.V. (2018b). The place and role of right depriving legal facts in the legal regulation mechanism of civil property relations. Utopia y Praxis Latinoamericana-Revista Internacional de Filosofia Iberoamericana y Teoria Social, 23(82), 171-183.

Kovalenko, O., Lobunets, V., Lazarev, M., Tarasyuk, A. (2007). On the implementation of the concept of development of engineering and pedagogical education in Ukraine. Problems of Engineering and Pedagogical Education, 18/19, 7-18.

Law of Ukraine No. 103/98-VP "On Vocational Education". (1998). Retrieved from: https://zakon.rada.gov.ua/laws/show/103/98-вp\#Text.

Misra, P.K. (2011). VET teachers in Europe: Policies, practices and challenges. Journal of Vocational Education \& Training, 63(1), 27-45. DOI: 10.1080/13636820.2011.552732.

Nychkalo, N. (2004). Labor market and problems of modernization of training of skilled workers. Vocational Education, 1, 4-12.

Oliynyk, V. (2003). Scientific bases of management of advanced training of pedagogical staff of vocational education. Kyiv: Millenium. 
Order of the Cabinet of Ministers of Ukraine No. 419-p "On approval of the Concept of implementation of the state policy in the field of vocational (vocational) education "Modern vocational (vocational) education" for the period up to 2027". (2019). Retrieved from: https://zakon.rada.gov.ua/laws/show/419-2019-\%D1\%80\#Text.

Radkevych, V. (2011). Scientific and methodical bases of modernization of the content of vocational education and training. Scientific Bulletin of the Institute of Vocational Education of the NAES of Ukraine. Professional Pedagogy, 1, 57-67.

Sergeeva, L. (2011). Modern trends in the formation of the content of advanced training of management staff of vocational education. The Origins of Pedagogical Skills. Pedagogical Sciences, 8(1), 262-266.

Shakuto, E.A., Dorozhkin, E.M., Kozlova, A.A. (2016). Management of teacher scientificmethodical work in vocational educational institutions on the basis of project-target approach. International Journal of Environmental and Science Education, 11(16), 88348845 .

Silaeva, I.Y. (2018). Advanced training as a guarantee of effective professional activity of teachers of vocational education. Image of a Modern Pedagogue, 6(183), 38-41. Retrieved from: http://isp.poippo.pl.ua/article/view/146965/149395.

Sirk, M., Liivik, R., Loogma, K. (2016). Changes in the professionality of vocational teachers as viewed through the experiences of long-serving vocational teachers in Estonia. Empirical Research in Vocational Education and Training, 8, article number 13. DOI: 10.1186/s40461-016-0039-7.

Skydan, O. (2011). Planning for sustainable rural development. Management Theory and Studies for Rural Business and Infrastructure Development, 26, 220-226.

Skydan, O., Nykolyuk, O., Pyvovar, P., Martynchuk, I. (2019). Methodological approach to the evaluation of agricultural business system flexibility. Management Theory and Studies for Rural Business and Infrastructure Development, 41(4), 444-462.

Stepanets, I. (2020). Monitoring the quality of scientific and methodical work in the context of the competence approach in higher pedagogical education. Scientific Notes of the Department of Pedagogy, 1(46), 43-52. DOI: 10.26565/2074-8167-2020-46-06.

Tolochko, S.V., Ridey, N.M. (2017). Theoretical substantiation of the need to form scientific and methodical competence of teachers in the system of postgraduate pedagogical education. ScienceRise. Pedagogical Education, 8, 14-19. DOI: 10.15587/25194984.2017.108974.

Vasylieva, N.V., Vasylieva, O.I., Prylipko, S.M., Kapitanets, S.V., Fatkhutdinova, O.V. (2020). Approaches to the formation of public administration in the context of decentralization reform in Ukraine. Cuestiones Politicas, 38(66), 301-320.

Vinichenko, M.V., Chulanova, O.L., Karacsony, P., Bogdan, E.S., Melnichuk, A.V., Makushkin, S.A. (2018a). Model of competences of graduates of high schools of engineering directions: research of stakeholders. Modern Journal of Language Teaching Methods, 8(3), 369-380.

Vinichenko, M.V., Chulanova, O.L., Oseev, A.A., Bogdan, E.S., Makushkin, S.A., Grishan, M.A. (2018b). Interaction of the higher education and key employer for the formation of the actual profile of the competences of graduates of engineering directions. Modern Journal of Language Teaching Methods, 8(5), 394-404.

Vinichenko, M.V., Melnichuk, A.V., Makushkin, S.A. (2018c). Implementation of game methods in the preparation of management personnel. In: 4th international conference on higher education advances, pp. 373-380. Valencia: Universitat Politécnica de Valencia.

Vvedensky, V.N. (2003). Modeling of professional possibility of pedagogy. Pedagogy, 10, 5455.

Website of the Department of Methods of Professional Education and Social and Humanitarian Disciplines. (2020). Retrieved from: http://methodica.inf.ua. 
Zashchirinskaia, O.V. (2020a). Patterns of interrelation between perception and understanding of images and texts with different degree of blur. Attention Perception \& Psychophysics, 82(3), 1368-1377.

Zashchirinskaia, O.V. (2020b). Specific features of the comprehension of texts and story pictures by adolescents with intellectual disturbances. Acta Neuropsychologica, 18(2), 221-231.

Zaslavska, S.I. (2015). Ways to improve advanced training of teachers of vocational education. Bulletin of Postgraduate Education: A Collection of Scientific Papers, 15(28), 63-74. 